\title{
THE PROFESSIONALIZATION OF DENTISTRY IN THE UNITED KINGDOM ${ }^{1}$
}

by

\author{
ERIC G. FORBES*
}

\section{INTRODUCTION}

During the 1840 s, dentistry began to progress from a secondary occupation by lay persons into an exclusive full-time practice. Only then did British dentists begin to organize themselves into societies and associations for the reform of the prevailing chaos. ${ }^{2}$ The first significant step was the attempt to form a faculty of dental surgeons that would confer diplomas. This was formally proposed by J. L. Levison of Birmingham in a letter dated 2 March 1841 to the editor of the Lancet $^{3}$ recommending certain distinguished members of the Royal College of Surgeons (RCS) as suitable examiners for what was eventually to become the Licentiateship in Dental Surgery (LDS). A few months later, a practising dentist, George Waite MRCS, ${ }^{4}$ sent a memorial to the RCS Council stressing the need for dentistry to be legally and professionally recognized as a legitimate branch of medical science, and recommending that the College institute a special qualifying examination. ${ }^{5}$ Then, in 1843, a four-man deputation to Anthony White, President of the RCS, requested that dental students be permitted to pursue a course of study similar to that of those who intended to practise surgery, and to have a similar diploma. However, White was of the opinion that every qualified dentist should be a member of his College; but in those days, no one engaged solely in practice as a dentist, aurist, oculist, orthopaedist, or midwife, was ever elected to that College.

The next attempt to place dentistry on a more stable footing owed its origins to a Bill to regulate the medical profession, introduced in 1844 by Sir James Graham, the Home Secretary. ${ }^{6}$ The friendship between Graham's brother and a leading dentist of that time, Arnold Rogers, ${ }^{7}$ led the latter to approach White with the request that his

\footnotetext{
*The Editors regret to announce that Professor Eric G. Forbes, PhD, MSc, MLitt, FRAS, FRSE, died while this paper was in press.

${ }^{1}$ Adapted for publication from the author's Menzies Campbell Lecture of the same title, read in Edinburgh on Friday, 25 May 1984.

${ }^{2} \mathrm{~N}$. David Richards, 'Dentistry in England in the 1840s: the first indications of a movement towards professionalization', Med. Hist., 1968, 12: 137-152.

${ }^{3} \mathrm{~J}$. L. Levison, 'Suggestions for a faculty of surgeon-dentists', Lancet, 1841, i: 898.

'Lilian Lindsay, 'Personalities of the past: I. G. D. Waite', Br. dent. J., 1955, 98: 28.

${ }^{5}$ George Waite, An appeal to the parliament, the medical profession, and the public, on the present state of dental surgery, London, 1841. See Richards, op. cit., note 2 above, pp. 142-143.

${ }^{B}$ A. B. Erickson, 'An early attempt at medical reform in England: 1844-5', J. Hist. Med., 1950, 5: 144-145. A fuller discussion is to be found in Charles Newman, The evolution of medical education in the nineteenth century, London, Oxford University Press, 1957.

${ }^{7}$ Lindsay, 'XVI. A. Rogers', loc. cit., note 4 above, p. 363.
} 


\section{E. G. Forbes}

Council seek powers under their new charter to establish a dental department and a diploma qualification in dental surgery. Unfortunately, however, the Bill itself was withdrawn, so there was no reaction to this appeal, although renewed pleas for the official recognition of dentistry and for a faculty of surgeon-dentists or college of dentists appear in the first (and only) two issues of the British Quarterly Journal of Dental Science (1843)-the first exclusively dental journal in Great Britain-and again in the early numbers of its successor, the Forceps, which was published fortnightly from January 1844 to March 1845 . In these, it was emphasized that the surgeons had their College, the apothecaries their Hall, the chemists their Pharmaceutical Society, and the veterinary surgeons their College, yet anyone could advertise as a dentist. Dentistry was an under-developed clinical specialism not practised in hospitals; its practitioners were jealous of their skills and techniques, textbooks were few, formal teaching almost non-existent, and there was internecine rivalry between surgeons and dentists as well as among dentists themselves. The great diversity in the social origins of practitioners and patients, and in the level of study, training, and quality of service provided, created further barriers. ${ }^{8}$

\section{EARLY DENTAL INSTITUTIONS}

The first indication that an organized movement might at last be under way was heralded by the publication in the Lancet on 25 August 1855 of a letter from the Croydon dentist Samuel Lee Rymer, ${ }^{9}$ renewing the suggestion of an RCS licence and urging the need for a college of dental surgery. ${ }^{10}$ Rymer subsequently called a meeting at which proposals were adopted for organizing a dental society and establishing a system of professional education and examination; on 16 December 1856, the College of Dentists of England was founded with James Robinson ${ }^{11}$ of Gower Street as its first president. Meanwhile, a small group of eminent London practitioners headed by John Tomes, ${ }^{12}$ the author of the influential textbook Dental physiology and surgery, had convened and formed themselves into the Odontological Society of London, with Samuel Cartwright ${ }^{13}$ as its first president. The clandestine manner in which this private society came into existence ${ }^{14}$ caused it to be received with very mixed feelings by those practitioners who were already members of the RCS yet had never been consulted, and by others who had acquired very high reputations as dentists without being members of the RCS. Naturally enough, both categories were offended, since some of the eighteen signatories of Tomes's memorial were of the same status as themselves.

The RCS insisted that all dentists should be members of the College, but Tomes believed that the additional three years' education required to obtain the specialist

\footnotetext{
${ }^{8}$ Richards, op. cit., note 2 above, pp. 148-152.

${ }^{\circ}$ Lindsay, 'II. S. L. Rymer', loc. cit., note 4 above, p. 69.

${ }^{10}$ Samuel Lee Rymer, 'Necessity for a college of dental surgery', Lancet, 1855, ii: 181.

${ }^{11}$ Lindsay, 'VI. J. Robinson', loc. cit., note 4 above, p. 176.

${ }^{12}$ Lindsay, 'XII. J. Tomes', ibid., p. 295.

${ }^{13}$ Lindsay, 'IX. S. Cartwright', ibid., p. 259.

${ }^{14} \mathrm{~A}$ detailed account of its origins and founder members is to be found in Alfred Hill, The history of the dental reform movement in the dental profession in Great Britain during the last twenty years, London, 1877 , pp. 58-74.
} 


\section{The professionalization of dentistry in the United Kingdom}

qualification would wreck Rymer's proposed scheme. The RCS's solicitor drafted a clause that gave the College the right to institute a new diploma after the Medical Act was passed in 1858. Forty-three candidates, including some distinguished names, presented themselves for the first examination for the Licentiate in Dental Surgery, held two years later, and all passed. Soon afterwards, the College of Dentists, which Rymer and his associates had formed, ceased to function and in 1863 it was amalgamated into the rechristened Odontological Society of Great Britain. ${ }^{15}$

By this time, the idea of founding an odonto-chirurgical society of Scotland ${ }^{\mathbf{1 6}}$ had already been suggested by Dr John Smith, surgeon-dentist to Queen Victoria. In a printed letter to the President of the Royal College of Surgeons of Edinburgh (RSCE) dated February 1858, he stressed that dentists should preferably possess a surgical diploma or equivalent qualification, plus a specialist dental qualification; or, alternatively, that a limited and special course of elementary practical and theoretical instruction be afforded. As a result of his efforts, a dental dispensary was opened in Drummond Street early in 1860, and placed under the control of a regularly constituted committee of management that issued appeals for public contributions. It was later transferred to Cockburn Street where, at a meeting in January 1865 , the suggestion to form an odonto-chirurgical society was again mooted and a code of laws drafted and subsequently circulated among members of the profession. However, it floundered on the question of what constituted qualification, and the organization was duly dissolved four months later. A more successful tactic was that of arranging a dinner in Edinburgh on the date when dental diplomas were awarded; and although this too was to experience minor setbacks, the Society was duly established in 1867.

Before its transformation into the Edinburgh Dental Hospital and School some twelve tears later, ${ }^{17}$ the Edinburgh Dental Dispensary was run by well-qualified surgeons such as Professors John Goodsir and James Spence of Edinburgh University, with Robert Nasmyth ${ }^{18}$ as the consultant surgeon-dentist. Professors Sir Robert Christison and Sir James Young Simpson were members of its board of management. A rule introduced in 1862 defined the eligibility of its medica-that is, dental-officers as people possessing the appropriate medical or surgical title qualifying for LDS registration and engaged in the practice of dental surgery, or those with at least twenty years' practical experience. Its affairs were placed on a sound administrative and financial footing, though voluntary subscriptions from members of the local public were disappointingly low and entirely inadequate to pay for nitrous oxide to be used to ease pain. Nevertheless, almost 5000 patients were treated in the first five years of its existence, and certificates of attendance there were recognized by the RCS of England as part of the curriculum for the diploma in dental surgery. Perhaps it is worth remarking that Lilian Murray, the first lady ever to

\footnotetext{
${ }^{15}$ F. F. Cartwright, 'The relationship of medicine and dentistry in the nineteenth century', Proc. R. Soc. Med., 1966, 59: 1237-1240, provides further information concerning these events.

${ }^{16}$ The fortunes of this society are well described by J. Menzies Campbell, From a trade to a profession: byways in dental history, Glasgow, [privately printed], 1958, ch. 13, pp. 144-158.

${ }^{17}$ William Guy, 'The story of the Edinburgh Dental Hospital and School', Dental Magazine and Oral Topics, 1935, 52: 27-39, 142-153, 240-254.

${ }^{18}$ Lindsay, 'XIV. R. Nasmyth', loc. cit., note 4 above, p. 334.
} 


\section{E. G. Forbes}

qualify in Britain as a dental surgeon (in 1895), was a graduate of this dental school. ${ }^{19}$ She was afterwards to marry a member of its dental staff, Robert Lindsay, ${ }^{20}$ and thus came to be better known under her married name both as a pioneer in the history of dentistry and a strong advocate of reform within the dental profession.

\section{THE BRITISH DENTAL ASSOCIATION}

Throughout the $1860 \mathrm{~s}$, a number of other dental societies, hospitals, and dispensaries were established in provincial English cities such as Liverpool, Plymouth, and Birmingham. ${ }^{21}$ This gave rise to renewed pleas for the establishment of a British dental association, which "will accomplish an amount of reform that has hitherto been unattainable by any existing organisation". ${ }^{22}$ A pamphlet on compulsory dental education and registration (1870), ${ }^{23}$ written by Charles James Fox, ${ }^{24}$ who was later to become editor and owner of the British Journal of Dental Science-the forerunner of the British Dental Journal-, was destined to cause quite a stir. Unlike most of his fellow practitioners, Fox was conscious of the need for wider local and provincial participation in any dental organization that hoped to claim a nationwide allegiance, and proposed that the London-based Odontological Society of Great Britain should, at certain intervals, elect its president from among its provincial members. In 1875, he arranged a meeting in Manchester, which closed with a resolution that he should form a committee to implement this intention. This event may be regarded as marking the beginning of a corporate movement in the cause of dental reform.

Fox's radical Dental Reform Committee recognized that the only way of remedying the evils of the time was to obtain an Act of Parliament, which meant that its sphere of operations had to be in London. ${ }^{25}$ Its president was Samuel Cartwright, elected after Tomes was obliged to decline on account of ill health, and after Fox had indicated a preference for waging a literary campaign through his journal. Cartwright was also president of the Association of Surgeons practising Dental Surgery, which wished dentistry to be regarded as a branch of surgery on a par with ophthalmology, otology, and gynaecology; and, as has previously been mentioned, president of the Odontological Society of Great Britain, which was neutral and non-political. Although these three organizations differed in their views regarding the means by

\footnotetext{
${ }^{19}$ This fact is referred to under 'Edinburgh' in an anonymous article published on $5 \mathrm{July} 1960$ in $\mathrm{Br}$. dent. J., 1960, 109: 1.

${ }^{20}$ Robert Lindsay was the first full-time dental secretary of the British Dental Association.

${ }^{21}$ The Birmingham Dental Hospital, founded as the Birmingham Dental Dispensary in January 1858, is the oldest dental hospital still in existence. See E. Muriel Spencer, 'Notes on the history of dental dispensaries', Med. Hist., 1982, 26: 47-66.

${ }^{22}$ N. David Richards, 'Hesitant beginnings: the establishment of the British Dental Association', in Ronald A. Cohen (editor), The advance of the dental profession: a centenary history 1880-1980, London, British Dental Association, 1979, p. 3.

${ }^{23}$ C. J. Fox, The dental diploma question: a plea for the admission to the dental examination of the Royal College of Surgeons, without curriculum, of all who were in practice as dentists ...prior to the Dental Charter of September 8, 1859, London, 1870.

${ }^{24}$ N. David Richards, 'Dentistry a hundred years ago: Charles James Fox-the forgotten man', Br. dent. J., 1972, 132: 235-242; see also, Lindsay, 'XXI. C. J. Fox', loc. cit., note 4 above, p. 455.

${ }^{25}$ Lilian Lindsay, 'Those London men' (Presidential address at the annual meeting of the Metropolitan Branch of the British Dental Association in London on 8 December 1932), Br. dent. J., 1933, 54: 49-54.
} 


\section{The professionalization of dentistry in the United Kingdom}

which dental surgeons should obtain legal recognition of their rights and status, the conflict of interests was balanced by their common resolve to abolish quackery from dentistry. ${ }^{26}$

Following numerous discussions and debates between the Reform Committee's secretary and dental practitioners and societies throughout Great Britain, a registration bill was drawn up and duly became the Dentists' Act, $1878,{ }^{27}$ whereby inter alia:

From and after 1st August 1879 a person shall not be entitled to take or use the name of dentist ... or dental practitioner, or any other name, title addition or description implying that he is registered under this Act, or that he is a person specially qualified to practise dentistry unless he is registered under the Act. ${ }^{28}$

The rights of medical practitioners to practise dentistry were also safeguarded; while fines of up to $£ 20$ could be imposed on anyone convicted for false assumption of title. Pharmacists were also permitted to extract teeth and carry out dental operations provided that no anaesthetic was administered..$^{29}$

The vexed question of registration was largely responsible for prompting the establishment in 1879 of the British Dental Association (BDA) with the Dental Reform Committee becoming its Representative Board. The first major task of this Board was to pass judgment on persons who appeared falsely or fraudulently to have had their names placed upon the Dentists' Register, published that same year ${ }^{30}$ The first secretary of the BDA, James Smith Turner, warned some 500 persons that they should withdraw their names, and many did so. He subsequently informed the General Medical Council (GMC) of the 400 or so who chose to ignore this warning, in the hope that they could be prosecuted. Thus the question of direct dental representation on the GMC was an important point in the evidence submitted by the BDA to the Royal Commission on the Medical Act, set up in $1882 .^{31}$ The main flaw in the Dentists' Act of 1878 was that while providing the means for dentists to register, it did nothing about those who did not register. Any unregistered person could still practise dentistry, provided that he was cautious as to how he advertised himself. For this reason, it was sometimes referred to as the charter of the unregistered dental practitioners.

Another loophole that was to become a source of longstanding grievance to the BDA was the opportunity given to ingenious persons by company laws to avoid the provisions of the Dentists' Act. Thus one of the first actions of John Tomes's son, Charles, when he was nominated in 1898 by the Privy Council to a seat on the GMC, was to approach the president of the Board of Trade with the request that certain of these laws be amended. ${ }^{32}$ The Companies Act of 1900 took some cognisance of this,

${ }^{26}$ Richards, op. cit., note 22 above, pp. 4-5.

27 'An Act to amend the Law relating to Dental Practitioners', [22 July 1878], 41 \& 42 Vict. ch. 33.

${ }^{28}$ Quoted from Sir Zachary Cope, 'The making of the dental profession in Britain' (Charles Edward Wallis Lecture on 23 June 1964), Proc. R. Soc. Med., 1964, 57: 919-926.

${ }^{29}$ This situation was to persist until the Dentists' Act of 1983 (note 55 below).

${ }^{30} \mathrm{~J}$. A. Donaldson, 'The Association and dental legislation', in Cohen (editor), op. cit., note 22 above, p. 13.

${ }^{31}$ Ibid., p. 15.

32 Ibid., p. 19. 


\section{E. G. Forbes}

though less than had been desired. From then onwards, there was a growing confidence in, and academic acceptance of, the dental profession. The LDS was gradually becoming recognized as the sign of a properly qualified dentist, but there were many who felt that the cause of dental education would be further advanced only if dentistry were to be made a university discipline with similar preliminary requirements to those for medicine. Retaining the connexion with medicine was widely recognized as being important for raising the status of the dentist, and was a policy still being advocated several decades later when a permanent split between the two professions seemed to be inevitable. ${ }^{33}$

A development of the dental profession that was to prove beneficial in this respect arose out of a BDA initiative in 1890 , when a national committee was appointed to investigate the teeth of schoolchildren. During the next seven years, seven annual reports on this theme were submitted to the Representative Board. The appointment of school dentists during those years led to the formation of the School Dentists' Society (1898), whose members were all registered dentists appointed to any public institution for children. ${ }^{34}$ During the first decade of the present century, the dental inspection of schoolchildren became merged into the major question of medical inspection, of which it naturally forms a part; and three reports in 1903-5 directed public attention to the importance of school medical inspection and treatment. ${ }^{35}$ Under the Education (Administrative Provisions) Act of 1907, such inspection was made obligatory, whereas medical (including dental) treatment was merely an executive power which local education authorities were enabled to exercise under certain conditions. From then on, both aspects were gradually developed as a branch of the school medical service.

In a paper to the Belfast meeting of the BDA in 1908, William Guy, dean of the Edinburgh Dental Hospital and School for thirty-four years, criticized and dismissed several bills that had been proposed as amendments to the Dentists' Act of 1878, recommending: the creation of a dental council; the production of a new dentists' register; the establishment of a state examination qualifying for that register, to be taken after a degree or diploma; and the prohibition of practice by unregistered persons. ${ }^{36}$ When he again raised these matters in Birmingham one year later, Guy gave priority to the issue of practice by unregistered persons, though making concessions to existing unregistered persons of proven ability. He further recommended that state recognition should be protected through levying an annual tax or licence, and that a general dental council be instituted.

Guy's concern with the dangers arising from incompetent practitioners, which were particularly apparent among the poorer classes in the community, was

\footnotetext{
${ }^{33}$ W. A. Bulleid, 'The separation of dentistry from medicine', Br. dent. J., 1937, 62: 113-121.

${ }^{34} \mathrm{~A}$ thorough historical survey of this aspect of the profession is contained in a series of twelve articles by Graham Turner, 'Organisation in the School Dental Service', ibid., 1971, 131: 33-36, 75-78, 127-129, 164-165, 207-210, 283-284, 329-332, 371-373, 417-418, 465-466, 511-514, 561-565.

${ }^{35}$ These were the Royal Commission on Physical Training, Scotland (1903), the Inter-Departmental Commission on Physical Deterioration (1904), and the Inter-Departmental Committee on Medical Inspection and Feeding of Children attending Public Elementary Schools (1905). See Stanley Gelbier and Sheila Randall, 'Charles Edward Wallis and the rise of London's school dental service', Med. Hist., 1982, 26: 395-404.

${ }^{36}$ Donaldson, op. cit., note 30 above, pp. 21-22.
} 


\section{The professionalization of dentistry in the United Kingdom}

undoubtedly well founded, as is testified by contemporary reports in the British Dental Journal and local newspapers. To quote but one of many such cases:

Hull County Court- $£ 15$ damages against T. H. Jubb for unskilful treatment. Fourteen teeth were broken by operator leaving nerves exposed. The operator was 21 years of age, had never attended any hospitals or lectures on dentistry. He had often extracted fourteen teeth at a time. The Judge stated that there was serious negligence. ${ }^{37}$

A serious challenge to the spirit of the Dentists' Act of 1878 was presented not only by the ignorance and incompetence of individual unregistered dentists, but by unregistered dental companies and societies attracting business by skilled advertising, house-to-house canvassing, and easy instalment schemes for the purchase of dentures. Many of these companies sent out agents to make periodical tours of the towns, advertising the particulars of their visits in the local press beforehand and hiring a consulting room (e.g., at a hotel) for the occasion. During the six-year period 1906-12, one central company founded by a foreigner, whose varied occupations bore no connection with dentistry, spawned no fewer than fifty-seven hygienic institutes as separate companies in the principal British and Irish towns. Most of these employed untrained people who would appear to have been public menaces, if one is to judge from the following newspaper reports which appeared during $1910:^{38}$

Durham Chronicle, 21 January 1910

Durham County Court-£56 damages v. Bishop Auckland Hygienic Institute. Doctor's evidence stated that part of a woman's jaw was literally torn away. She seemed to be suffering from cocaine poisoning and from slight lockjaw and bled for five or six days. He had never seen a mouth in such a condition in his life; it was torn to pieces. There was a compound fracture of the jaw.

\section{Glasgow Herald, 3 February 1910}

Glasgow Sheriff Court- $\mathbf{\$ 1 0 0}$ damages against the Glasgow Hygienic Institute for injury done by unskilful dental operation. Patient's jaw fractured in extraction of seventeen teeth and mouth very much lacerated, his general health being seriously and injuriously affected in consequence.

\section{Waterford Evening News, 6 May 1910}

Waterford County Court- $£ 20$ damages and expenses v. Hygienic Institute for overdose of cocaine to J. O'Brien-evidence of cocaine poisoning necessitating medical attendance to save life.

South Wales Daily News, 6 May 1910

Cardiff County Court-Judgement for $£ 8$ and costs v. Hygienic Institute, Cardiff, for illness of patient for 14 days.

Not only did such institutes charge high fees for their deadly services; they also had no assets and hence no financial liability for injuries caused! Judgments against them were prevented from being operative through the appointment of receivers. Small wonder, therefore, that they were to disappear almost as quickly as they had arisen!

37 'Damages for unskilful treatment at Hull', Br. dent. J., 1912, 33: 185.

${ }^{38}$ These cases are cited in summary from among the evidence submitted to the Acland Committee as affording striking instances of the abuse of the Companies Act for the practice of dentistry by unqualified practitioners. See the Acland Report, op. cit., note 42 below, p. 8. 


\section{E. G. Forbes}

It is, however, only fair to say that there were other unregistered dental companies in existence at the same time that strove to maintain proper ethical standards. Moreover, the 1600-strong Incorporated Dental Society Ltd provided clinics and, lectures and examined its new recruits before admitting them to membership. The Macdonald Manufacturing Company Ltd, which had many branches throughout the country, likewise paid close attention to the selection of suitable assistants and to the supervision of their work. This company's size and stability were guarantees that all bona fide claims would be investigated. Thus a Select Committee of the House of Lords set up in 1907 to consider a private member's bill providing for the prohibition of dental work by incorporated companies, ${ }^{39}$ decided to insert an amendment recognizing and protecting the vested interests of established dental companies such as these.

The answer was seen to lie in control rather than in prohibition; and control could best be exercised through legislation, for which registration was the political lever. The Poisons and Pharmacy Act (1908) established a precedent, by ruling that a body corporate, or in Scotland a firm or partnership, may carry on the business of a pharmaceutical chemist, or chemist and druggist, if it were either directed or managed personally by a superintendent registered in that discipline. After this, it seemed sensible to enact similar conditions for dentists. Thus a Bill was drafted and considered by the GMC, which finally resolved in 1916:

\footnotetext{
That the Lord President of the Privy Council be informed that in the opinion of the [General Medical] Council it is urgently necessary in the public interest that steps be taken to amend the Dentists Act in order that the public may be better enabled to distinguish qualified from unqualified practitioners in dentistry..$^{40}$
}

The fact that no fewer than twenty-six different descriptions and titles were then being used with impunity by unregistered practitioners or dental companies was in itself the source of much confusion in the public mind. ${ }^{41}$

\section{THE ACLAND REPORT}

In response to a plea from the GMC, the Privy Council set up a committee under the chairmanship of Francis Acland MP, to investigate "the extent and gravity of the evils of dental practice by persons not qualified under the Dentists Act". Its exhaustive report, published in $1919,{ }^{42}$ provides a detailed survey of malpractices resulting in grave personal pain or injury, the needless extraction of sound or only slightly decayed teeth, and the application of artificial teeth over decayed stumps and into septic mouths. Cocaine poisoning was frequent, and even deaths from the unskilful administration of anaesthetics were not uncommon. An attitude referred to on several occasions was the lack of enthusiasm on the part of the general public for

\footnotetext{
39 'Dental Companies (Restriction of Practice) Bill' (1907).

${ }^{40}$ Cope, op. cit., note 28 above, p. 922.

${ }^{41}$ These were listed in a confidential memorandum from the BDA to the Acland Committee, and published in its Report of 1919 (op. cit., note 42 below, p. 12.

${ }^{42} \mathrm{Cmd}$. 33. 'Report of the Committee appointed by the Lord President of the Council to enquire into the extent and gravity of the evils of dental practice by persons not qualified under the Dentists' Act' (London, 1919). This is referred to elsewhere in these notes as the Acland Report.
} 


\section{The professionalization of dentistry in the United Kingdom}

conservative dentistry, which ran contrary to the prime aim of registered practitioners; namely to preserve natural teeth with a view to reducing the incidence of related medical conditions such as oral sepsis, chronic gastritis, indigestion, anaemia, tonsillitis, rheumatism, and general debility. Septic mouths were recognized as predisposing a consumptive condition and infection, as well as prejudicing the prospects of recovery; which is why the London Insurance Committee was able to establish a statistical correlation between "un-cared for" mouths and pulmonary tuberculosis.

The poorer classes, in particular, were not prepared to spend either their time or their hard-earned money to preserve their teeth, preferring to allow them to decay until the pain became unbearable; then to have them extracted. False teeth were generally too expensive for the young servant girls who were among the chief sufferers, hence the Domestic Workers' Friendly Society was the first insurance scheme to make arrangements for the dental treatment of its members, including free conservative treatment and artificial dentures at half price. However, ignorance and indifference, as well as the lack of proper facilities for dental treatment, were also determining factors. The example of this society was soon followed by the Association of Approved Societies, representing over two million insured persons, which instituted a public dental service to provide adequate treatment for all who were in need of it, irrespective of their financial position. These societies were often in localities not served by dental hospitals, as the latter were confined to towns with universities and dental schools.

Another example of private enterprise was the Scottish Dentists' Association Ltd, incorporated in 1914, which originated from the establishment of two dental clinics. in densely populated districts of Glasgow and a guaranteed capital of $£ 400$. It was staffed by local registered dentists who worked a rota from 7 to 9 p.m. throughout the week, charging for extractions $6 d$. per tooth without anaesthetic or $1 s$. with anaesthetic; and $3 s .6 d ., 4 s .6 d$., or one guinea for fillings, depending on whether amalgam, synthetic porcelain, or gold was used. Full dentures were $£ 210$ s. $0 d$., single teeth $5 s$., and remodels $£ 13 s .6 d{ }^{43} \mathrm{~A}$ similar service was inaugurated a few years later in Dundee. Both of these initiatives flagged when many of the operators were called to active service during the First World War, but thousands of patients nevertheless received skilled treatment at their hands.

The motivation behind these private schemes was to a large extent altruistic. Statistics presented to the Acland Committee by the Army Council's Southern Command revealed that no fewer than 160 out of 304 medical cases were found to be suffering from ailments directly attributable to defective teeth (e.g., gastritis and indigestion), with a further 60-70 indirectly attributable (e.g., rheumatism and rheumatoid arthritis). The situation was equally serious among the civilian population. The Prudential Approved Societies with three million subscribers were, for example, in no doubt that there were thousands of persons receiving sickness benefit who would not be doing so had they received proper dental treatment. ${ }^{44}$

Thus there were strong medical and economic reasons for advocating that more

${ }^{43}$ Ibid., §129, p. 35.

${ }^{44}$ Ibid., §58, p. 18. 


\section{E. G. Forbes}

public money should be spent on the nationwide improvement of dental services than was already being provided by the Local Government Board for tuberculosis cases, maternity and child welfare work (for children under five years of age). Board of Education grants to assist local educational authorities to treat children in primary schools had likewise to be extended if the United Kingdom were to assume responsibility for the preservation of the good health and working efficiency of its citizens. By giving priority to schoolchildren of all ages, and inculcating in them at the same time an awareness of the health hazards arising from tooth decay, it was anticipated that the need for treatment of the adult population would greatly diminish.

However, a greater degree of expenditure and dental propaganda to change the pervasive attitude of indifference and neglect were not in themselves sufficient to effect the drastic reforms required. Steps had also to be taken to reduce, and eventually to overcome, the shortage of qualified dentists. One major reason why there had been little increase in the registration of dentists during the first two decades of this century was that non-registered practitioners could still earn a living. Other reasons were the expense and length of time involved in qualifying for a registrable diploma. Latin, for example, was still a compulsory subject in the preliminary examinations for entry into university dental schools. If this requirement were to be waived, and passes in chemistry and physics in the higher school matriculation examinations accepted in lieu of a professional examination normally taken after only six months of intensive study, the standard four-year course of professional study could be reduced to three years. Moreover, dental students would benefit more from classes in anatomy, medicine, and surgery specially designed with their needs in view, rather than from those which they were obliged to share with medical students. A further boost to dental education would be the provision of more Board of Education grants to provincial dental schools of university standing; part of this subsidy could be allocated for the training and supervision of competent dental dressers or nurses, who could be usefully and safely employed in school dental work. Provisions were also desirable for research scholarships to investigate the causes of dental diseases, and for the training of dental mechanics. All of the above recommendations feature in the Acland Report, and were duly implemented.

\section{THE TEVIOT REPORTS}

The Dentists' Act of $1921^{45}$ established the Dental Board, with Francis Acland as its first chairman. It shared responsibility for the educational and ethical control of the profession with the GMC for the next twenty-five years until the General Dental Council (GDC) ultimately gave dentists full autonomy from the medical profession. An amendment which came into force in $1923^{46}$ gave special consideration to those who had served in the armed forces and who now wished to take up dentistry as a profession-a useful concession that had the effect of more than doubling the number of dentists previously registered (e.g., from 5,831 to 12,762 in the year 1923-24).

45 'An Act to amend the Dentists Act, 1878, and the provisions of the Medical Act, 1886, amending that Act' [28 July 1921] $11 \& 12$ Geo. 5, ch. 21 .

46 'An Act to amend the Dentists Act, 1921', [2 August 1923] 13 \& 14 Geo. 5, ch. 36. 


\section{The professionalization of dentistry in the United Kingdom}

By this time, dentists had formed themselves into three professional associations - the BDA (incorporated in 1880), the Incorporated Dental Society (with origins going back to 1892, representing in particular those dentists admitted to the register by the 1921 Act), and the Public Dental Service Association (instituted in 1922 to represent dentists giving service to insured persons). A desire to establish an independent general dental council to replace the Dental Board was strongly felt by Acland and others in the late 1930s, but no political action was taken until 1943 when, at the height of World War II, an inter-departmental committee under the chairmanship of Charles Ian Kerr, 1st Baron Teviot, was established to consider and report on the measures required to improve the whole realm of dental education, research, and legislation. Because of the consideration then being given to the idea of establishing a national health service, and the Ministry of Health's need for guidance on general principles concerning the dental aspects of such a scheme, the Teviot Committee was asked in 1944 to produce an interim report. ${ }^{47}$ Its final report ${ }^{48}$ was duly published early in 1946, by which time Clement Attlee's Labour Government had come into power.

The interim report was based upon a great deal of oral and written evidence gathered by the Teviot Committee over a period of one and a half years. It included a brief general account of the current situation with regard to the dental profession in the United Kingdom, incorporating its history, government, education, present and prospective numbers in the profession, the salient features of the main publicly-organized dental services and the public attitude towards them, with comments on the relation of dental to general health.

More particularly, details were given concerning the proportional grants or loans made by the Dental Board during the two decades 1923-42 for student bursaries, new dental schools (salaries and buildings) and university chairs, research and clinical researches, and the dental health education of the community, out of the revenue derived from the $£ 5$ registration fees from individual dentists. There were then thirteen dental licensing bodies and sixteen dental schools in the United Kingdom, yet most of the staff in those schools were employed on a part-time (paid or honorary) basis. Career prospects for dentists and ancillary workers (such as dental hygienists, dressers, and mechanics) were not attractive; while the public as a whole tended to hold the profession in low esteem and display an apathy towards obtaining treatment, which reflected not only the natural fear of pain but also ignorance of the importance of dental health.

The two "horses" in the race for improvement, which had to be kept in rough equality but goaded to run as fast as possible, were supply (or need) and demand. A greater demand for dental treatment would encourage recruitment to the profession, and conversely a well-staffed service would stimulate the demand. But where was the country going to find suitable recruits? The age-distribution of the 15,192 dentists on the register at the end of $1942^{49}$ exhibited the heavy weighting in the higher (over forty-five) age-groups resulting from the special provisions of the 1921 Act; from

${ }^{47} \mathrm{Cmd}$. 6565 'Interim report of the Inter-Departmental Committee on Dentistry' (London, 1944).

${ }^{48}$ Cmd. 6727 'Inter-Departmental Committee on Dentistry. Final report'. [18 October 1945] (London, 1946); alias the Teviot Report.

${ }^{10}$ Op. cit., note 47 above; Appendix A, Tab. 1 . 


\section{E. G. Forbes}

which it was evident that there would shortly be a rapid loss of names due to retirement, especially since the annual intake during the war years had fallen to below 300. The problem for the future, therefore, was recognized as that of maintaining an adequate supply of dentists to cope with the anticipated increase in public demand for treatment arising from the introduction of a comprehensive dental service paid for by the community as a whole. The effect of changes in national diet, the influence of progress in dental research upon attitudes towards dental education, and the results of making better provision for special classes such as expectant and nursing mothers, children, and adolescents, were unpredictable factors affecting the reversible equation between supply and demand; but a steady annual intake of 900 into the dental schools (allowing for a ten per cent failure rate) was deemed necessary if the long-term target of 20,000 were to be reached.

These interim recommendations were confirmed in the final report of 18 October $1945^{50}$ addressed to the new Minister of Health, Aneurin Bevan, and the Secretary of State for Scotland, Joseph Westwood. This urged much greater publicity through films and broadcasting as another means of encouraging recruitment into the dental profession, and better working conditions and financial incentives to place it on a par with medicine if the stimulus were to be maintained. All dental schools should in future be affiliated to universities-Edinburgh and Glasgow were then notable exceptions to the general rule-and receive government funding from the University Grants Committee. In view of the shortage of registered dentists, it was recommended that dental students be given priority when proposals for introducing a local authority grant system for all properly qualified schoolchildren came to be considered.

\section{THE MCNAIR REPORT}

With one exception, ${ }^{51}$ the Teviot Committee decided to recommend that the Dental Board be replaced by the General Dental Council (GDC). Like the Public Dental Service Association, the Committee felt that the dental profession had now "earned the right to self-government" and was "sufficiently adult" to be entrusted with an individual authority on any or all matters concerned with the discipline, registration, and education of the dental profession. This did not imply that dentists would henceforth become isolated from the medical profession: independence need not mean isolation. As far as discipline was concerned, it would suffice if the new body were empowered to subpoena witnesses (for which precedents existed) without taking evidence on oath. The respective duties of dental attendants, mechanics (or technicians), and hygienists were also clearly defined, and the detailed legislative

\footnotetext{
${ }^{\text {so }}$ Op. cit., note 48 above.

${ }^{51}$ The exception was Major-General J. Philip Helliwell, later Chief Dental Officer of the London County Council's school dental service. His opposition to the proposed autonomy of the dental profession was shared by the Royal College of Surgeons of England (the most important licensing body for dental surgeons in Britain) and Guy's Hospital (which housed one of the largest dental schools in London). He also objected to dentists supplying false teeth, since this was incompatible with their primary commitment to preserving natural teeth. He thought that dental technicians should be given the requisite training in prosthesis and taking impressions of the mouth. He also advocated health education in schools to combat the prevailing lack of knowledge of elementary physiology, the causation of disease, and personal hygiene.
} 


\section{The professionalization of dentistry in the United Kingdom}

amendments required for the enactment of the Committee's recommendations were listed.

Ten more years were to elapse before another bill, drafted in the light of the Teviot Committee's reports, finally came into force as the Dentists' Act of 4 July $1956 .^{52}$ The choice of date-Independence Day for the Americans-was deliberate, as the terms of this Act finally gave dentists full autonomy and control over entry into and expulsion from their profession. Yet, notwithstanding this achievement, which represented the culmination of over a century of endeavour to free dentistry from the evils that I have already briefly depicted, recruitment into the profession continued to be disturbingly low.

Another committee, chaired by Sir Arnold Duncan McNair, was set up to examine this problem. It found that the main reasons were lack of financial security and unsatisfactory career opportunities for dentists in research, consultancy, and hospital posts, and offered proposals for improving the situation..$^{53}$ Nevertheless, two more decades were to elapse before the recommended target figure of 20,000 registered dentists was attained. The government's policy of encouraging an experimental scheme for supplementing dental services through ancillary workers pressurized the GDC into developing new legislation relating to the training and enrolment on certification of dental auxiliaries and hygienists.

Britain's entry into the EEC and subsequent governmental legislation affecting the mobility of dentists and conditions of employment generally have now resulted in the entire Dentists' Act of 1956 being repealed, and substantial amendments being made to the consolidating Dentists' Act of $1957 .{ }^{54}$ The Dentists' Act $1983,{ }^{55}$ which replaced these, has made substantial changes in the constitution of the GDC and clarified the precise meaning of the term "fitness to practise". Nowadays, a dentist does not merely require to be skilful and of good character in order to be legally "fit". He or she must also speak good English and remain healthy in both body and spirit! A health committee will now decide whether a dentist's poor health impairs the quality of his work, and if it does, he may find himself having to answer to the Professional Conduct Committee, which now replaces the harsher sounding "Disciplinary Committee". With control such as this, the public may at last rest assured that their dental interests have been well catered for by the profession. Yet, despite these measures, the GDC is still restricted in what it can do to protect patients who feel (rightly or wrongly) that the treatment they have received from a registered dentist is below the high standard now expected.

\footnotetext{
s2 'An Act to amend the law relating to dentists' [15 March 1956] 4 \& 5 Eliz. 2, ch. 29.

${ }^{53}$ Donaldson, op. cit., note 30 above, pp. 34-35.

54 'An Act to consolidate the enactments relating to dentists and other dental workers with corrections and improvements authorised under the Consolidation of Enactments (Procedure) Act, 1949' [6 June 1957] 5 \& 6 Eliz. 2, ch. 28.

55 'An Act to amend the Dentists Act 1957 and for connected purposes' [13 May 1983] 31 \& 32 Eliz. 2, ch. 38 .
} 